\title{
Article \\ Concise Synthesis of Functionalized Cyclobutene Analogues for Bioorthogonal Tetrazine Ligation
}

\author{
Jiayu Sun ${ }^{1,+}$, Jie $\mathrm{Li}^{1, \dagger}$, Hongbao Sun ${ }^{1, \dagger}$, Chunling $\mathrm{Li}^{2,3, *}$ and Haoxing $\mathrm{Wu}^{1, *}$ \\ 1 Department of Radiology, West China Hospital, Sichuan University, Guo Xue Xiang 37, \\ Chengdu 610041, China; sjy080512@163.com (J.S.); lj_jievip@163.com (J.L.); hbsun07@sina.com (H.S.) \\ 2 Department of Neurosurgery, Sichuan Provincial People's Hospital, \\ University of Electronic Science and Technology of China, Chengdu 610072, China \\ 3 Chinese Academy of Sciences Sichuan Translational Medicine Research Hospital, Chengdu 610072, China \\ * Correspondence: Lcl1206778081@163.com (C.L.); haoxingwu@scu.edu.cn (H.W.); \\ Tel.: +86-028-65261615 (H.W.) \\ + These authors contributed equally to this work.
}

check for updates

Citation: Sun, J.; Li, J.; Sun, H.; Li, C.; $\mathrm{Wu}, \mathrm{H}$. Concise Synthesis of Functionalized Cyclobutene Analogues for Bioorthogonal Tetrazine Ligation. Molecules 2021, 26, 276. https://doi.org/molecules26020276

Academic Editors: Pierre Audebert, Jean-Cyrille Hierso and

Giuseppe Cirillo

Received: 19 December 2020

Accepted: 5 January 2021

Published: 8 January 2021

Publisher's Note: MDPI stays neutral with regard to jurisdictional clai$\mathrm{ms}$ in published maps and institutional affiliations.

Copyright: $(\odot 2021$ by the authors. Licensee MDPI, Basel, Switzerland. This article is an open access article distributed under the terms and conditions of the Creative Commons Attribution (CC BY) license (https:// creativecommons.org/licenses/by/ $4.0 /)$.

\begin{abstract}
Novel bioorthogonal tools enable the development of new biomedical applications. Here we report the concise synthesis of a series of aryl-functionalized cyclobutene analogues using commercially available starting materials. Our study demonstrates that cyclobutene acts as a small, strained dienophile to generate stable substrates suitable for bioorthogonal tetrazine ligation.
\end{abstract}

Keywords: functionalized cyclobutene analogues; concise synthesis; tetrazine ligation; bioorthogonal chemistry

\section{Introduction}

Tetrazine has attracted increasing attention since the emergence of bioorthogonal chemistry [1-4]. Recent clinical trials have highlighted the biomedical usefulness of the bioorthogonal reaction between tetrazine and dienophiles, an inverse electron demand Diels-Alder (IEDDA) reaction [5-8]. A wide range of dienophiles, each with different advantages and limitations, have been developed as IEDDA substrates for various research purposes. In particular, highly strained trans-cyclooctenes (TCO) can react with tetrazine very rapidly, enabling a low concentration reaction in vivo in a short time [9-11]. The reaction of allyl-substituted TCO with tetrazine leads to a cascade elimination that has been widely used in the design of prodrugs [12-15]. Bicyclooctynes $(\mathrm{BCN})$ react rapidly with tetrazine to afford pyridazine as a single product, which can facilitate downstream fluorogenic probe design [16-18]. Cyclopropene units have also emerged as alternative, more compact tags that can react quickly with tetrazine and have proven useful in studies of metabolic engineering [19-22]. The strained dienophiles norbornenes and norbornadienes, although they react less quickly with tetrazine, serve as a handle for covalent biomolecule labeling or offer a click-to-release feature that can be exploited for templatepromoted turnover amplification, allowing the detection of endogenous oncogenic microRNAs [23-27]. In addition, the vinyl ether group is small and easy to prepare and can be decorated onto polymers and fluorophores under mild conditions [28-32]. Therefore, the development of novel dienophiles with different features is expected to provide straightforward access to new applications.

Cyclobutenes, as small and strained dienophiles, may be good mini-tags for labeling proteins, since their compactness makes it unlikely that they will disturb the proteins' physiological functions. In addition, cyclobutene is less volatile than cyclopropene, which makes the synthesis of mini-tags easier. Despite the advantages of cyclobutene, only the synthesis and bioorthogonal properties of alkyl-substituted cyclobutene analogues have been investigated so far [33]. 
In this study, we report the concise synthesis of a series of aryl-substituted cyclobutene derivatives from commercially available 1,3-cyclobutanediol derivatives. We also systematically investigated the stability of the derivatives and their kinetics in bioorthogonal reactions.

\section{Results and Discussion}

We used 1,3-cyclobutanediol (1) as the starting material for the synthesis of the desired cyclobutene derivatives, and we assumed that the two hydroxyl groups would be directly converted into a double bond or functional groups upon reaction under appropriate conditions. Treating 1,3-cyclobutanediol with $p$-toluenesulfonyl chloride $(\mathrm{TsCl})$ and triethylamine (TEA) yielded the mono-toluene-4-sulfonate ester 2 in moderate yield. After flash column purification, the sulfonate ester reacted with a series of $p$-substituted thiophenols (3a-3d), forming the corresponding thioethers $\mathbf{4 a}-\mathbf{4 d}$ in up to $86 \%$ yield. Subsequent tosylation and elimination generated four novel cyclobutene derivatives (6a-6d) bearing a phenyl sulfide moiety useful for further functionalization (Scheme 1A). Phenolic cyclobutene derivatives were prepared by slightly modifying the above mentioned steps and by using the commercially available 3-(benzyloxy)cyclobutyl-4-methylbenzenesulfonate (7). We followed a three-step process (Scheme 1B) to prepare two cyclobutene analogues (11a and $11 b)$ in overall yield of $22-23.5 \%$. None of the intermediates or final products were volatile, and all were stored for months at $-20^{\circ} \mathrm{C}$.

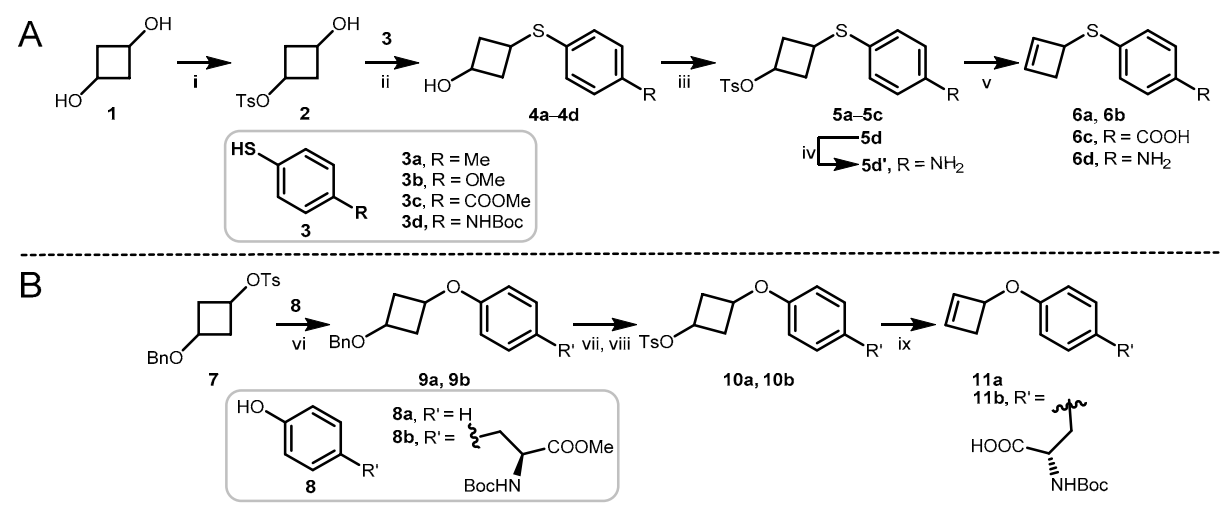

Scheme 1. Synthesis of the cyclobutene derivatives. (A) Synthesis of phenylthio cyclobutene derivatives 6a-6d; (B) Synthesis of phenolic cyclobutene derivatives 11a and 11b. (i) $\mathrm{TsCl}_{1} \mathrm{Et}_{3} \mathrm{~N}$, DCM, r.t., $9 \mathrm{~h}$; (ii) ${ }^{t} \mathrm{BuOK},{ }^{t} \mathrm{BuOH}, 80{ }^{\circ} \mathrm{C}, 7 \mathrm{~h}, 32-86 \%$; (iii) $\mathrm{TsCl}, \mathrm{Et}_{3} \mathrm{~N}, \mathrm{DCM}$, r.t., overnight, 55-79\%; (iv) TFA, DCM, r.t., 1 h; (v) ${ }^{t} \mathrm{BuOK}, \mathrm{DMSO}$, r.t., $1 \mathrm{~h}, 46-89 \%$; (vi) $\mathrm{Cs}_{2} \mathrm{CO}_{3}, \mathrm{DMF}, 80{ }^{\circ} \mathrm{C}, 8 \mathrm{~h}, 48-70 \%$; (vii) $\mathrm{Pd} / \mathrm{C}$, $\mathrm{EtOH}, \mathrm{H}_{2}$, r.t., overnight; (viii) $\mathrm{Et}_{3} \mathrm{~N}$, TsCl, DCM, r.t., 20 h, 70-86\% for two steps; (ix) ${ }^{t} \mathrm{BuOK}$, DMSO, r.t., $1 \mathrm{~h}, 45-57 \%$. TsCl: 4-tosyl chloride; TFA: trifluoroacetic acid.

The synthesized cyclobutene derivatives were then incubated in phosphate-buffered saline (PBS) with 50\% N,N-dimethylformamide (DMF) as co-solvent at $37^{\circ} \mathrm{C}$, and their stability was monitored over time using liquid chromatography-mass spectrometry. All cyclobutenes were relatively stable under these buffer conditions, irrespective of the phenyl substituent. After incubation for $12 \mathrm{~h}, 90 \%$ of the original analogues were still present, except for compound 11a (87\%) (Figure 1A). There was slight degradation for all analogues, with 79.4-92.7\% of the original material remaining at $24 \mathrm{~h}$. These aryl-substituted cyclobutenes are slightly less stable than some other known dienophiles, such as TCO [9], cyclopropene units $[19,34]$, and norbornene derivatives $[23,26]$. However, they are facilely prepared, so they could be a choice in the toolbox for preliminary studies. 
A

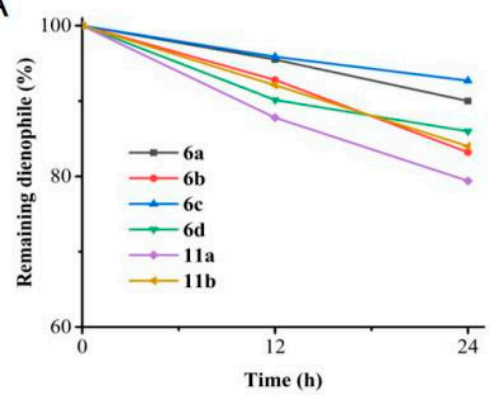

B

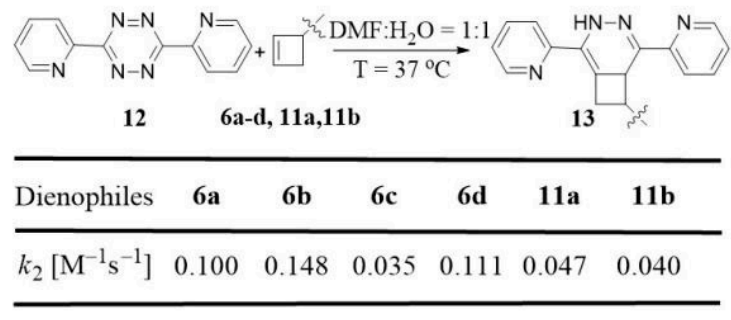

Figure 1. (A) Stability of the cyclobutene derivatives $\mathbf{6 a - 6 d}, \mathbf{1 1 a}$, and $\mathbf{1 1} \mathbf{b}$ during incubation in $N, N$ dimethylformamide/phosphate-buffered saline (1:1) at $37^{\circ} \mathrm{C}$ for $24 \mathrm{~h}$. Absorption was monitored using high-performance liquid chromatography. (B) Kinetics of the inverse electron demand Diels-Alder (IEDDA) reactions between tetrazine 12 and 6a-6d, 11a, and 11b. Conditions: $0.5 \mathrm{mM}$ tetrazine, $5 \mathrm{mM}$ dienophile, $\mathrm{DMF} / \mathrm{H}_{2} \mathrm{O}(1: 1), 37^{\circ} \mathrm{C}$.

Next, we reacted the six cyclobutene analogues $\mathbf{6 a - 6 d}, \mathbf{1 1 a}$, and $\mathbf{1 1} \mathbf{b}$ with di-pyridyltetrazine under pseudo-first-order conditions (Figure 1B). The reactants were dissolved in $50 \%$ DMF in PBS, and the reaction at $37^{\circ} \mathrm{C}$ was monitored using UV-vis spectroscopy to track the disappearance of the characteristic absorption peak of tetrazine at $520 \mathrm{~nm}$ over time. The IEDDA reaction between the cyclobutenes and tetrazine proceeded with rate constants of $0.04-0.15 \mathrm{M}^{-1} \mathrm{~s}^{-1}$, similar to those of $N$-acylazetines with tetrazine [35,36], and faster than those of terminal alkenes with tetrazine [37]. Electron-donating substituents on the phenyl ring of the cyclobutene analogues improved their reactivity, while a benzoic acid group slightly reduced the reactivity of the double bond. In order to examine the structure of the IEDDA product, the dihydropyridazine intermediate between $\mathbf{6 a}$ and $\mathbf{1 2}$ was further oxidized using 1.1 equivalent of 2,3-dichloro-5,6-dicyano-1,4-benzoquinone (DDQ), affording a single pyridazine product 14 as the major product in $82 \%$ overall yield. The structure of $\mathbf{1 4}$ was confirmed by nuclear magnetic resonance (NMR) spectroscopy (Figure 2) which indicated that almost no ring-opening or sideproduct formation had occurred in the two-step reactions.

A

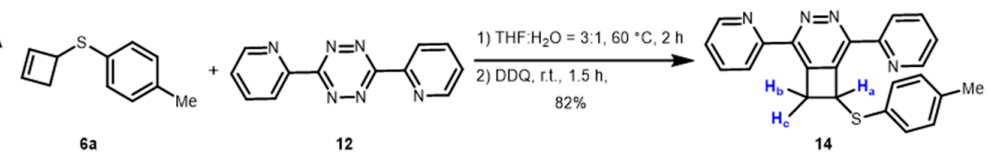

B

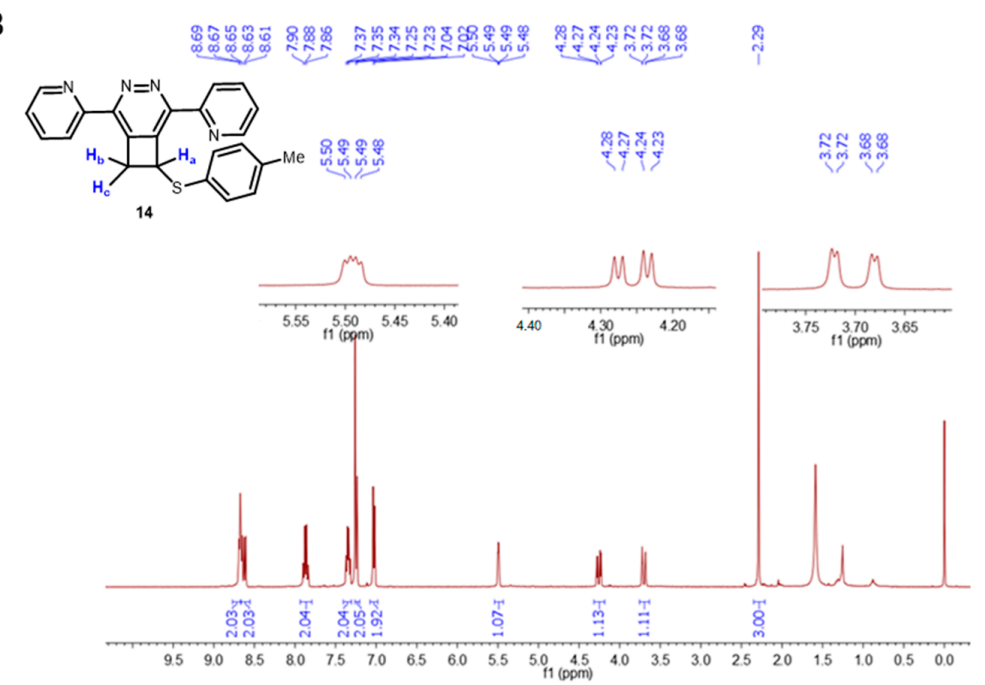

Figure 2. (A) IEDDA-oxidation cascade reaction of cyclobutene 6a with dipyridinetetrazine $\mathbf{1 2}$. (B) The ${ }^{1} \mathrm{H}-\mathrm{NMR}$ spectrum of compound 14. 
To examine the applicability of our cyclobutenes for biomolecular labeling, we first synthesized a cyclobutene- $N$-hydroxysuccinimide (NHS) amide (17) using the cyclobutene derivative $6 \mathrm{~d}$ via a two-step process (Scheme 2). As a proof of concept, the cyclobuteneNHS conjugate 17 was added to bovine serum albumin (BSA) to create a cyclobutene "handle" for bioorthogonal labeling. The modified BSA was incubated with a tetrazine-Cy5 near-infrared probe (19, H-Tz-Cy5) for $4 \mathrm{~h}$. Subsequent analysis with sodium dodecyl sulfate-polyacrylamide gel electrophoresis showed that the cyclobutene-modified BSA was fluorescent, but the control reactions lacking the conjugate 17 or the Cy5 probe were not (Figure 3). A rough estimation of the yield of the labeling reaction on the model BSA protein was calculated to be about $29.1 \%$. These results suggest that cyclobutene derivatives can be used to label proteins via tetrazine bioorthogonal reactions.
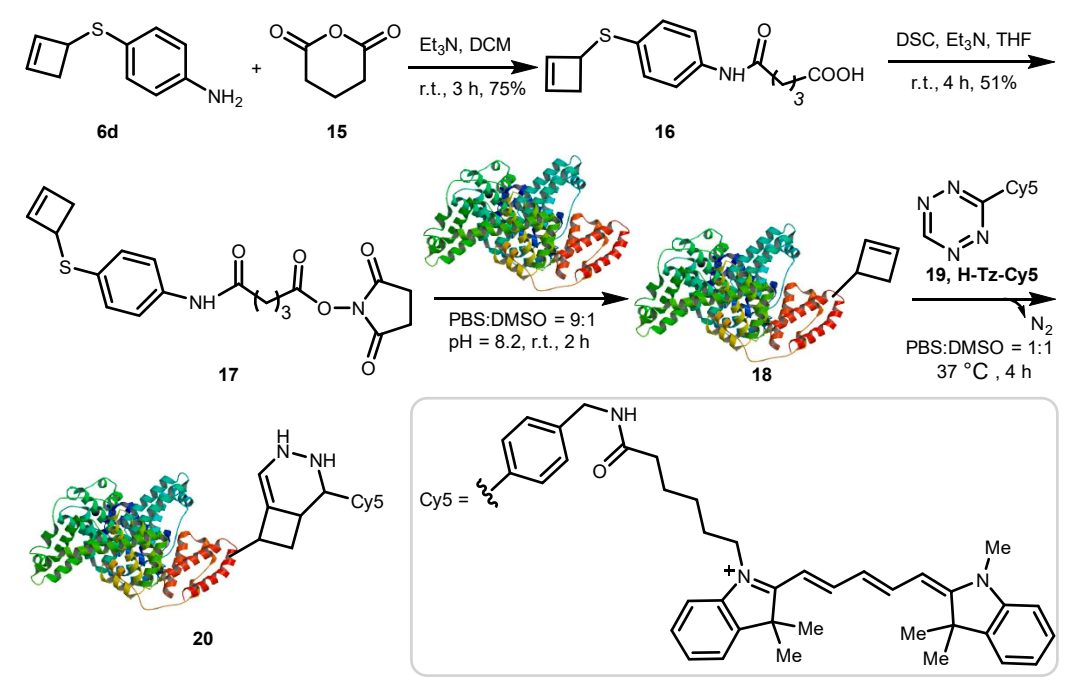

Scheme 2. In vitro cyclobutene modification and bioorthogonal labeling of protein bovine serum albumin (BSA).

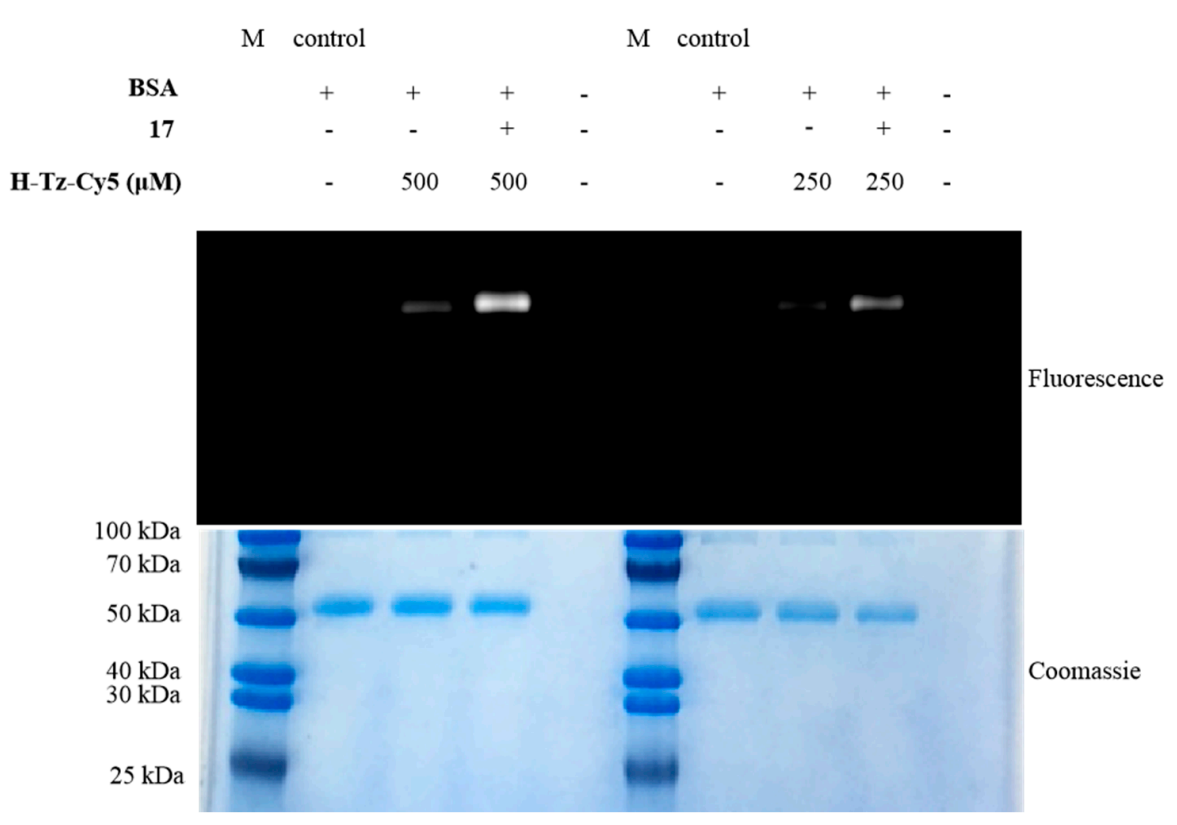

Figure 3. In vitro labeling of bovine serum albumin (BSA) via cyclobutene-tetrazine bioorthogonal reaction. Upper panel: fluorescent image of the same gel before Coomassie blue staining. Lower panel: Coomassie-blue-stained gel of BSA modified through IEDDA reaction between conjugate 17 and the Cy5-containing fluorescent probe $19(250 \mu \mathrm{M}$ or $500 \mu \mathrm{M})$. Control reactions contained only BSA or BSA with only the Cy5 probe $(250 \mu \mathrm{M}$ or $500 \mu \mathrm{M})$. "M": protein marker. 


\section{Experimental Section}

3.1. Materials

All chemical reagents were purchased from commercial sources (Adamas-Beta, Shanghai, China; Energy Chemical, Shanghai, China; or Sigma-Aldrich, St. Louis, MO, USA) and used without further purification. The silica gel plates were purchased from Yantai Jiangyou Silica Gel Development (silica $200 \times 200$ mm, pH 6.2-6.8, glass-backed). All reactions were monitored based on absorbance at $254 \mathrm{~nm}$ and liquid chromatography-mass spectrometry (Agilent-Technologies Infinity Lab LC/MSD system, Agilent Technologies Inc., Santa Clara, CA, USA). Products were purified by flash silica gel column chromatography (SepaBeanTM, Santai Technologies, Changzhou, Jiangsu, China). ${ }^{1} \mathrm{H}-$ and ${ }^{13} \mathrm{C}-\mathrm{NMR}$ spectra were recorded on a Bruker (Billerica, MA, USA) NMR spectrometer $\left({ }^{1} \mathrm{H}, 400 \mathrm{MHz}\right.$; ${ }^{13} \mathrm{C}, 101 \mathrm{MHz}$ ) and high-resolution mass spectrometry (Bruker, Billerica, MA, USA) was performed on a Bruker Daltonics Data analysis 3.4 system. Reaction kinetics were determined on a Quawell Scientific Q6000+ microvolume spectrophotometer. Protein gels were analyzed for Cy5 fluorescence using the ChemiDoc ${ }^{\mathrm{TM}}$ MP imaging system (Bio-Rad Laboratories Inc., Hercules, CA, USA).

\subsection{Synthesis and Characterization}

\subsubsection{Synthesis of 3-Hydroxycyclobutyl 4-Methylbenzenesulfonate (2)}

A solution of tosyl chloride ( $\mathrm{TsCl}, 22 \mathrm{mg}, 0.12 \mathrm{mmol}, 0.7$ equiv) in dichloromethane (DCM, $0.5 \mathrm{~mL}$ ) was added dropwise with stirring to a mixture of 1,3-cyclobutanediol $(15 \mathrm{mg}$, $0.17 \mathrm{mmol}, 1.0$ equiv) and TEA ( $47 \mu \mathrm{L}, 0.34 \mathrm{mmol}, 2.0$ equiv) in DCM $(0.3 \mathrm{~mL})$ at $0{ }^{\circ} \mathrm{C}$ under Ar. The reaction mixture was stirred at room temperature for $9 h$, followed by evaporation in vacuo. The obtained residue was purified by silica gel column chromatography $(\mathrm{PE} / \mathrm{EA}=2: 1)$ to afford the desired analogue 2 in $38 \%$ yield as a light yellow oil.

\subsubsection{Synthesis of Compounds $\mathbf{4 a}-\mathbf{4} \mathbf{d}$}

To synthesize 3-(p-tolylthio)cyclobutanol (4a), potassium tert-butoxide $(265 \mathrm{mg}, 2.35 \mathrm{mmol}$, 1.3 equiv) was added under intense stirring to a solution of 3-hydroxycyclobutyl-4-methyl benzenesulfonate ( $439 \mathrm{mg}, 1.81 \mathrm{mmol}, 1.0$ equiv) and 4-methylbenzenethiol ( $270 \mathrm{mg}, 2.18 \mathrm{mmol}$, 1.2 equiv) in tert-butanol $(8 \mathrm{~mL})$ at room temperature under Ar. The mixture was stirred at $80^{\circ} \mathrm{C}$ for $7 \mathrm{~h}$. After completion of the reaction monitored by TLC, the crude mixture was quenched with water and extracted with ethyl acetate. The combined organic phases were washed with brine, dried over anhydrous $\mathrm{Na}_{2} \mathrm{SO}_{4}$, and evaporated in vacuo. The residue was purified by silica gel column chromatography (PE/EA $=3: 1)$ to afford $4 \mathbf{a}(186 \mathrm{mg}, 86 \%)$ as a yellow solid. ${ }^{1} \mathrm{H}-\mathrm{NMR}\left(400 \mathrm{MHz}, \mathrm{CDCl}_{3}\right) \delta 7.16(d, J=8.1 \mathrm{~Hz}, 2 \mathrm{H}), 7.10(d, J=8.0 \mathrm{~Hz}, 2 \mathrm{H}), 4.63-4.56(m$, $1 \mathrm{H}), 3.85-3.79(m, 1 \mathrm{H}), 2.46-2.34(m, 4 \mathrm{H}), 2.32(\mathrm{~s}, 3 \mathrm{H}), 1.99(\mathrm{~s}, 1 \mathrm{H}) .{ }^{13} \mathrm{C}-\mathrm{NMR}\left(101 \mathrm{MHz}, \mathrm{CDCl}_{3}\right)$ $\delta 136.2,132.9,129.8,129.7,66.3,39.6,33.9,21.1$. HRMS $[\mathrm{M}+\mathrm{H}]^{+} \mathrm{m} / z$ calcd. for $\left[\mathrm{C}_{11} \mathrm{H}_{15} \mathrm{OS}\right]^{+}$ 195.0838, found 195.0837.

To synthesize 3-((4-methoxyphenyl)thio)cyclobutanol (4b), potassium tert-butoxide (105 mg, $0.94 \mathrm{mmol}, 1.3$ equiv) was added under intense stirring to a solution of 3hydroxycyclobutyl-4-methylbenzenesulfonate $(170.3 \mathrm{mg}, 0.72 \mathrm{mmol}, 1.0$ equiv) and 4methoxybenzenethiol (121 $\mathrm{mg}, 0.86 \mathrm{mmol}, 1.2$ equiv) in tert-butanol $(4 \mathrm{~mL})$ at room temperature under Ar. The mixture was stirred at $80^{\circ} \mathrm{C}$ for $7 \mathrm{~h}$. After completion of the reaction monitored by TLC, the crude mixture was quenched with water and extracted with ethyl acetate. The combined organic phases were washed with brine, dried over anhydrous $\mathrm{Na}_{2} \mathrm{SO}_{4}$, and evaporated in vacuo. The residue was purified by silica gel column chromatography (PE/EA $=20: 1)$ to afford $4 \mathbf{b}(81 \mathrm{mg}, 77 \%)$ as a white solid. ${ }^{1} \mathrm{H}-\mathrm{NMR}(400 \mathrm{MHz}$, $\left.\mathrm{CDCl}_{3}\right) \delta$ 7.31-7.26 (m, 2H), 6.87-6.81 (m, 2H), 4.58-4.52 (m, 1H), $3.79(\mathrm{~s}, 3 \mathrm{H}), 3.77-3.69(\mathrm{~m}$, $1 \mathrm{H}), 2.34(\mathrm{t}, J=6.4 \mathrm{~Hz}, 4 \mathrm{H}), 1.90(\mathrm{~s}, 1 \mathrm{H}) .{ }^{13} \mathrm{C}-\mathrm{NMR}\left(101 \mathrm{MHz}, \mathrm{CDCl}_{3}\right) \delta$ 159.1, 133.2, 126.4, $114.7,66.2,55.4,39.5,35.2$.

To synthesize methyl 4-((3-hydroxycyclobutyl)thio)benzoate (4c), potassium tertbutoxide (304 mg, $2.70 \mathrm{mmol}, 1.3$ equiv) was added under intense stirring to a solution of 3-hydroxycyclobutyl-4-methylbenzenesulfonate (504 mg, $2.08 \mathrm{mmol}, 1.0$ equiv) and 
methyl 4-mercaptobenzoate $(420 \mathrm{mg}, 2.50 \mathrm{mmol}, 1.2$ equiv) in tert-butanol $(8 \mathrm{~mL})$ at room temperature under Ar. The mixture was stirred at $80^{\circ} \mathrm{C}$ for $7 \mathrm{~h}$. After completion of the reaction monitored by TLC, the crude mixture was quenched with water and extracted with ethyl acetate. The combined organic phases were washed with brine, dried over anhydrous $\mathrm{Na}_{2} \mathrm{SO}_{4}$, and evaporated in vacuo. The residue was purified by silica gel column chromatography $(\mathrm{PE} / \mathrm{EA}=2: 1)$ to afford $4 \mathrm{c}(200 \mathrm{mg}, 48 \%)$ as a white solid. ${ }^{1} \mathrm{H}-\mathrm{NMR}(400$ $\left.\mathrm{MHz}_{\mathrm{CDCl}}\right) \delta 7.91(\mathrm{~d}, J=8.3 \mathrm{~Hz}, 2 \mathrm{H}), 7.15(\mathrm{~d}, J=8.3 \mathrm{~Hz}, 2 \mathrm{H}), 4.75-4.57(\mathrm{~m}, 1 \mathrm{H}), 3.98-3.92$ $(m, 1 \mathrm{H}), 3.89(\mathrm{~s}, 3 \mathrm{H}), 2.60-2.48(\mathrm{~m}, 2 \mathrm{H}), 2.43-2.37(m, 2 \mathrm{H}), 2.13(\mathrm{~s}, 1 \mathrm{H}) .{ }^{13} \mathrm{C}-\mathrm{NMR}(101 \mathrm{MHz}$, $\left.\mathrm{CDCl}_{3}\right) \delta 167.0,144.5,130.1,126.7,126.0,66.1,52.2,52.1,39.4,31.9$. HRMS $[\mathrm{M}+\mathrm{Na}]^{+} \mathrm{m} / z$ calcd. for $\left[\mathrm{C}_{12} \mathrm{H}_{14} \mathrm{NaO}_{3} \mathrm{~S}\right]^{+} 261.0556$, found 261.0563 .

To synthesize tert-butyl (4-((3-hydroxycyclobutyl)thio)phenyl)carbamate (4d), potassium tert-butoxide (200 mg, $1.78 \mathrm{mmol}, 1.3$ equiv) was added under intense stirring to a solution of 3-hydroxycyclobutyl-4-methylbenzenesulfonate (331 mg, $1.36 \mathrm{mmol}, 1.0 \mathrm{equiv})$ and methyl tert-butyl (4-mercaptophenyl)carbamate ( $370 \mathrm{mg}, 1.64 \mathrm{mmol}, 1.2 \mathrm{equiv})$ in tert-butanol $(8 \mathrm{~mL})$ at room temperature under Ar. The mixture was stirred at $80{ }^{\circ} \mathrm{C}$ for $7 \mathrm{~h}$. After completion of the reaction monitored by TLC, the crude mixture was quenched with water and extracted with ethyl acetate. The combined organic phases were washed with brine, dried over anhydrous $\mathrm{Na}_{2} \mathrm{SO}_{4}$, and evaporated in vacuo. The residue was purified by silica gel column chromatography $(\mathrm{PE} / \mathrm{EA}=2: 1)$ to afford $4 \mathrm{~d}(146 \mathrm{mg}, 32 \%)$ as a brown solid. ${ }^{1} \mathrm{H}-\mathrm{NMR}\left(400 \mathrm{MHz}, \mathrm{CDCl}_{3}\right) \delta 7.29(\mathrm{~d}, J=8.4 \mathrm{~Hz}, 2 \mathrm{H}), 7.22(\mathrm{~d}, J=8.6 \mathrm{~Hz}, 2 \mathrm{H}), 6.48(\mathrm{~s}$, $1 \mathrm{H}), 4.63-4.49(\mathrm{~m}, 1 \mathrm{H}), 3.82-3.72(\mathrm{~m}, 1 \mathrm{H}), 2.36(\mathrm{dd}, J=12.8,6.4 \mathrm{~Hz}, 4 \mathrm{H}), 1.86(\mathrm{~s}, 1 \mathrm{H}), 1.51$ (s, 9H). ${ }^{13} \mathrm{C}-\mathrm{NMR}\left(101 \mathrm{MHz}, \mathrm{CDCl}_{3}\right) \delta 152.7,137.2,131.4,129.7,119.2,80.8,66.2,39.5,34.5$, 28.4. HRMS $[\mathrm{M}-\mathrm{H}]^{-} \mathrm{m} / z$ calcd. for $\left[\mathrm{C}_{15} \mathrm{H}_{20} \mathrm{NO}_{3} \mathrm{~S}\right]^{-} 294.1169$, found 294.1167 .

\subsubsection{Synthesis of Compounds $\mathbf{5 a}-\mathbf{5 d}$}

To synthesize 3-( $p$-Tolylthio)cyclobutyl-4-methylbenzenesulfonate (5a), a solution of $\mathrm{TsCl}$ (365 mg, $1.91 \mathrm{mmol}, 2.0$ equiv) in DCM (5 mL) was added dropwise under stirring to a mixture of 3-( $p$-tolylthio)cyclobutanol (186 mg, $0.96 \mathrm{mmol}, 1.0$ equiv), TEA (400 $\mu \mathrm{L}, 2.87 \mathrm{mmol}, 3$ equiv), and 4-dimethylaminopyridine (DMAP) (23 mg, $0.19 \mathrm{mmol}, 0.2$ equiv) in DCM $(5 \mathrm{~mL})$ at $0{ }^{\circ} \mathrm{C}$ under Ar. The resulting mixture was stirred at room temperature overnight. After completion, the reaction was quenched with water and extracted with ethyl acetate. The combined organic phases were washed with brine, dried over anhydrous $\mathrm{Na}_{2} \mathrm{SO}_{4}$, and evaporated in vacuo. The residue was purified by silica gel column chromatography (PE/EA $=2: 1)$ to afford $5 \mathbf{a}(261 \mathrm{mg}$, $78 \%)$ as a light yellow oil. ${ }^{1} \mathrm{H}-\mathrm{NMR}\left(400 \mathrm{MHz}, \mathrm{CDCl}_{3}\right) \delta 7.76(d, J=8.3 \mathrm{~Hz}, 2 \mathrm{H}), 7.33(d$, $J=8.0 \mathrm{~Hz}, 2 \mathrm{H}), 7.11(q, J=8.3 \mathrm{~Hz}, 4 \mathrm{H}), 5.03-4.96(m, 1 \mathrm{H}), 3.84-3.73(m, 1 \mathrm{H}), 2.70-2.56(m, 2 \mathrm{H})$, $2.45(\mathrm{~s}, 3 \mathrm{H}), 2.36-2.26(\mathrm{~m}, 5 \mathrm{H}) .{ }^{13} \mathrm{C}-\mathrm{NMR}\left(101 \mathrm{MHz}, \mathrm{CDCl}_{3}\right) \delta 145.0,136.9,133.8,131.7,130.4$, $130.0,129.9,128.0,73.9,37.2,34.6,21.8,21.2$. HRMS $[\mathrm{M}+\mathrm{Na}]^{+} \mathrm{m} / z$ calcd. for $\left[\mathrm{C}_{18} \mathrm{H}_{20} \mathrm{NaO}_{3} \mathrm{~S}_{2}\right]^{+}$ 371.0746, found 371.0749 .

To synthesize 3-((4-methoxyphenyl)thio)cyclobutyl 4-methylbenzenesulfonate (5b), a solution of $\mathrm{TsCl}(90.7 \mathrm{mg}, 0.48 \mathrm{mmol}, 2.0$ equiv) in DCM (2 mL) was added dropwise under stirring to a mixture of 3-((4-methoxyphenyl)thio)cyclobutanol (50 mg, $0.24 \mathrm{mmol}$, 1.0 equiv), triethylamine (TEA, $100 \mu \mathrm{L}, 0.71 \mathrm{mmol}, 3$ equiv), and 4-dimethylaminopyridine (DMAP) (5.8 mg, $0.05 \mathrm{mmol}, 0.2 \mathrm{equiv})$ in DCM (2 mL) at $0{ }^{\circ} \mathrm{C}$ under Ar. The resulting mixture was stirred at room temperature overnight. After completion, the reaction was quenched with water and extracted with ethyl acetate. The combined organic phases were washed with brine, dried over anhydrous $\mathrm{Na}_{2} \mathrm{SO}_{4}$, and evaporated in vacuo. The residue was purified by silica gel column chromatography $(\mathrm{PE} / \mathrm{EA}=5: 1)$ to afford $5 \mathbf{b}(47.6 \mathrm{mg}$, $55 \%)$ as a white solid. ${ }^{1} \mathrm{H}-\mathrm{NMR}\left(400 \mathrm{MHz}, \mathrm{CDCl}_{3}\right) \delta 7.75(\mathrm{~d}, J=8.3 \mathrm{~Hz}, 2 \mathrm{H}), 7.33(\mathrm{~d}$, $J=8.1 \mathrm{~Hz}, 2 \mathrm{H}), 7.25(\mathrm{~d}, J=8.9 \mathrm{~Hz}, 2 \mathrm{H}), 6.83(\mathrm{~d}, J=8.8 \mathrm{~Hz}, 2 \mathrm{H}), 4.97-4.90(m, 1 \mathrm{H}), 3.79$ (s, $3 \mathrm{H}), 3.74-3.67(m, 1 \mathrm{H}), 2.63-2.51(\mathrm{~m}, 2 \mathrm{H}), 2.44(\mathrm{~s}, 3 \mathrm{H}), 2.30-2.25(\mathrm{~m}, 2 \mathrm{H}) .{ }^{13} \mathrm{C}-\mathrm{NMR}(101$ $\left.\mathrm{MHz}, \mathrm{CDCl}_{3}\right) \delta 159.5,145.0,133.9,133.7,130.0,127.9,125.2,114.8,73.9,55.4,37.0,35.8,21.7$. HRMS $[\mathrm{M}+\mathrm{Na}]^{+} m / z$ calcd. for $\left[\mathrm{C}_{18} \mathrm{H}_{20} \mathrm{NaO}_{4} \mathrm{~S}_{2}\right]^{+} 387.0695$, found 387.0700.

To synthesize methyl 4-((3-(tosyloxy)cyclobutyl)thio)benzoate (5c), a solution of TsCl (318.8 mg, $1.67 \mathrm{mmol}, 2.0$ equiv) in DCM (3 mL) was added dropwise under stirring to a mix- 
ture of methyl 4-((3-hydroxycyclobutyl)thio)benzoate (199 mg, 0.84 mmol, 1.0 equiv), TEA $(350 \mu \mathrm{L}, 2.5 \mathrm{mmol}, 3 \mathrm{equiv})$, and 4-dimethylaminopyridine (DMAP) (20.4 mg, $0.16 \mathrm{mmol}$, 0.2 equiv) in DCM $(4 \mathrm{~mL})$ at $0{ }^{\circ} \mathrm{C}$ under Ar. The resulting mixture was stirred at room temperature overnight. After completion, the reaction was quenched with water and extracted with ethyl acetate. The combined organic phases were washed with brine, dried over anhydrous $\mathrm{Na}_{2} \mathrm{SO}_{4}$, and evaporated in vacuo. The residue was purified by silica gel column chromatography (PE/EA $=5: 1)$ to afford $5 \mathrm{c}(260 \mathrm{mg}, 79 \%)$ as a white solid. ${ }^{1} \mathrm{H}-\mathrm{NMR}\left(400 \mathrm{MHz}, \mathrm{CDCl}_{3}\right) \delta 7.91(\mathrm{~d}, J=8.6 \mathrm{~Hz}, 2 \mathrm{H}), 7.77(\mathrm{~d}, J=8.3 \mathrm{~Hz}, 2 \mathrm{H}), 7.34(\mathrm{~d}$, $J=8.0 \mathrm{~Hz}, 2 \mathrm{H}), 7.11(\mathrm{~d}, J=8.5 \mathrm{~Hz}, 2 \mathrm{H}), 5.09-5.02(m, 1 \mathrm{H}), 3.98-3.93(m, 1 \mathrm{H}), 3.89(\mathrm{~s}, 3 \mathrm{H})$, 2.85-2.69 (m, 2H), $2.45(\mathrm{~s}, 3 \mathrm{H}), 2.40-2.33(\mathrm{~m}, 2 \mathrm{H}) .{ }^{13} \mathrm{C}-\mathrm{NMR}\left(101 \mathrm{MHz}, \mathrm{CDCl}_{3}\right) \delta 166.7,145.1$, $143.2,133.6,130.2,130.0,127.9,127.2,126.4,73.4,52.2,37.0,32.5,21.8$. HRMS [M+Na $]^{+} \mathrm{m} / z$ calcd. for $\left[\mathrm{C}_{19} \mathrm{H}_{20} \mathrm{NaO}_{5} \mathrm{~S}_{2}\right]^{+} 415.0644$, found 415.0652 .

To synthesize 3-((4-((tert-butoxycarbonyl)amino)phenyl)thio)cyclobutyl4-methylbenzenesulfonate (5d), a solution of $\mathrm{TsCl}(155 \mathrm{mg}, 0.81 \mathrm{mmol}, 2.0$ equiv) in DCM (2 mL) was added dropwise under stirring to a mixture of tert-butyl (4-((3-hydroxycyclobutyl)thio)phenyl)carbamate (120 mg, $0.41 \mathrm{mmol}, 1.0$ equiv), TEA (170 $\mu \mathrm{L}, 1.22 \mathrm{mmol}, 3$ equiv), and 4-dimethylaminopyridine (DMAP) (10 mg, $0.08 \mathrm{mmol}, 0.2$ equiv) in DCM $(2 \mathrm{~mL})$ at $0{ }^{\circ} \mathrm{C}$ under Ar. The resulting mixture was stirred at room temperature overnight. After completion, the reaction was quenched with water and extracted with ethyl acetate. The combined organic phases were washed with brine, dried over anhydrous $\mathrm{Na}_{2} \mathrm{SO}_{4}$, and evaporated in vacuo. The residue was purified by silica gel column chromatography $(\mathrm{PE} / \mathrm{EA}=5: 1)$ to afford $\mathbf{5 d}(136 \mathrm{mg}, 74 \%)$ as a light yellow oil. ${ }^{1} \mathrm{H}-\mathrm{NMR}\left(400 \mathrm{MHz}, \mathrm{CDCl}_{3}\right) \delta 7.75(\mathrm{~d}, J=8.3 \mathrm{~Hz}, 2 \mathrm{H}), 7.31(\mathrm{dd}, J=15.9,8.4 \mathrm{~Hz}, 4 \mathrm{H}), 7.19(\mathrm{~d}$, $J=8.6 \mathrm{~Hz}, 2 \mathrm{H}), 6.51(\mathrm{~s}, 1 \mathrm{H}), 5.04-4.89(\mathrm{~m}, 1 \mathrm{H}), 3.77-3.71(\mathrm{~m}, 1 \mathrm{H}), 2.64-2.52(\mathrm{~m}, 2 \mathrm{H}), 2.44(\mathrm{~s}$, $3 \mathrm{H}), 2.31-2.25(m, 2 \mathrm{H}), 1.51(\mathrm{~s}, 9 \mathrm{H}) .{ }^{13} \mathrm{C}-\mathrm{NMR}\left(101 \mathrm{MHz}, \mathrm{CDCl}_{3}\right) \delta 152.7,145.0,137.8,133.7$, $132.2,130.0,128.3,127.9,119.2,80.9,73.9,37.0,35.1,28.4,21.8$. HRMS [M-H] ${ }^{-} m / z$ calcd. for $\left[\mathrm{C}_{22} \mathrm{H}_{26} \mathrm{NO}_{5} \mathrm{~S}_{2}\right]^{-} 448.1258$, found 448.1256 .

\subsubsection{Synthesis of Compounds $\mathbf{6 a}-\mathbf{6 d}$}

To synthesize cyclobut-2-en-1-yl( $p$-tolyl)sulfane (6a), potassium tert-butoxide (56 mg, $0.5 \mathrm{mmol}, 2.0$ equiv) was dissolved in dry DMSO $(1 \mathrm{~mL})$ under Ar, forming a colorless solution. Then, a solution of 3-( $p$-tolylthio)cyclobutyl-4-methylbenzenesulfonate ( $87 \mathrm{mg}$, $0.25 \mathrm{mmol}, 1.0$ equiv) in dry DMSO $(1 \mathrm{~mL})$ was added slowly to the colorless solution, and the resulting mixture was stirred at room temperature for $1 \mathrm{~h}$. Water was then added slowly, followed by ethyl acetate. The separated water phase was extracted with ethyl acetate three times, and the combined organic phases were washed once with water. The final organic phase was dried over anhydrous $\mathrm{Na}_{2} \mathrm{SO}_{4}$ and evaporated in vacuo. The residue was purified by silica gel column chromatography (PE) to afford compound 6a (38 mg, $86 \%)$ as a light yellow oil. ${ }^{1} \mathrm{H}-\mathrm{NMR}\left(400 \mathrm{MHz}, \mathrm{CDCl}_{3}\right): \delta 7.25(d, J=8.0 \mathrm{~Hz}, 2 \mathrm{H}), 7.09(d$, $J=7.9 \mathrm{~Hz}, 2 \mathrm{H}), 6.10(d d, J=17.4,2.5 \mathrm{~Hz}, 2 \mathrm{H}), 4.28(d, J=3.7 \mathrm{~Hz}, 1 \mathrm{H}), 3.03(d d, J=13.8$, $3.9 \mathrm{~Hz}, 1 \mathrm{H}), 2.49(d, J=13.8 \mathrm{~Hz}, 1 \mathrm{H}), 2.31(s, 3 \mathrm{H}) .{ }^{13} \mathrm{C}-\mathrm{NMR}\left(101 \mathrm{MHz}, \mathrm{CDCl}_{3}\right): \delta 138.1$, $137.5,136.5,132.4,130.7,129.7,46.9,40.1,21.2$. HRMS $[\mathrm{M}+\mathrm{H}]^{+} m / z$ calcd. for $\left[\mathrm{C}_{11} \mathrm{H}_{13} \mathrm{~S}\right]^{+}$ 177.0732, found 177.0740 .

To synthesize cyclobut-2-en-1-yl(4-methoxyphenyl)sulfane (6b), potassium tert-butoxide (29.3 mg, $0.26 \mathrm{mmol}, 2.0$ equiv) was dissolved in dry DMSO $(1 \mathrm{~mL})$ under Ar, forming a colorless solution. Then, a solution of 3-((4-methoxyphenyl)thio)cyclobutyl 4-methylbenzenesulfonate ( $47.6 \mathrm{mg}, 0.13 \mathrm{mmol}, 1.0$ equiv) in dry DMSO $(1 \mathrm{~mL})$ was added slowly to the colorless solution, and the resulting mixture was stirred at room temperature for $1 \mathrm{~h}$. Water was then added slowly, followed by ethyl acetate. The separated water phase was extracted with ethyl acetate three times, and the combined organic phases were washed once with water. The final organic phase was dried over anhydrous $\mathrm{Na}_{2} \mathrm{SO}_{4}$ and evaporated in vacuo. The residue was purified by silica gel column chromatography (PE) to afford compound $6 \mathbf{b}(24.5 \mathrm{mg}, 89 \%)$ as a light yellow oil. ${ }^{1} \mathrm{H}-\mathrm{NMR}\left(400 \mathrm{MHz}, \mathrm{CDCl}_{3}\right) \delta 7.35(\mathrm{~d}, J=8.7 \mathrm{~Hz}, 2 \mathrm{H}), 6.84(\mathrm{~d}, J=8.7 \mathrm{~Hz}, 2 \mathrm{H}), 6.07$ $(\mathrm{dd}, J=14.4,2.6 \mathrm{~Hz}, 2 \mathrm{H}), 4.19(\mathrm{~d}, J=3.9 \mathrm{~Hz}, 1 \mathrm{H}), 3.80(\mathrm{~s}, 3 \mathrm{H}), 2.97(\mathrm{dd}, J=13.8,4.0 \mathrm{~Hz}, 1 \mathrm{H}), 2.46$ 
$(\mathrm{d}, J=13.8 \mathrm{~Hz}, 1 \mathrm{H}) .{ }^{13} \mathrm{C}-\mathrm{NMR}\left(101 \mathrm{MHz}, \mathrm{CDCl}_{3}\right) \delta 159.2,138.3,137.2,134.1,125.6,114.4,55.4$, 47.9, 39.8. HRMS $[\mathrm{M}+\mathrm{H}]^{+} \mathrm{m} / \mathrm{z}$ calcd. for $\left[\mathrm{C}_{11} \mathrm{H}_{13} \mathrm{OS}\right]^{+} 193.0682$, found 193.0686.

To synthesize 4-(cyclobut-2-en-1-ylthio)benzoic acid (6c), potassium tert-butoxide $(11.45 \mathrm{mg}, 0.10 \mathrm{mmol}, 2.0$ equiv) was dissolved in dry DMSO $(0.5 \mathrm{~mL})$ under $\mathrm{Ar}$, forming a colorless solution. Then, a solution of methyl 4-((3-(tosyloxy)cyclobutyl)thio)benzoate (20 mg, $0.05 \mathrm{mmol}, 1.0$ equiv) in dry DMSO $(0.5 \mathrm{~mL})$ was added slowly to the colorless solution, and the resulting mixture was stirred at room temperature for $1 \mathrm{~h}$. Water was then added slowly, followed by ethyl acetate. The separated water phase was extracted with ethyl acetate three times, and the combined organic phases were washed once with water. The final organic phase was dried over anhydrous $\mathrm{Na}_{2} \mathrm{SO}_{4}$ and evaporated in vacuo. The residue was purified by silica gel column chromatography (PE/EA $=1: 1)$ to afford compound $\mathbf{6 c}(5.4 \mathrm{mg}, 47 \%)$ as a white solid. ${ }^{1} \mathrm{H}-\mathrm{NMR}(400 \mathrm{MHz}, \mathrm{DMSO}) \delta 7.85$ $(\mathrm{d}, J=8.4 \mathrm{~Hz}, 2 \mathrm{H}), 7.34(\mathrm{~d}, J=8.4 \mathrm{~Hz}, 2 \mathrm{H}), 6.25(\mathrm{~d}, J=24.8 \mathrm{~Hz}, 2 \mathrm{H}), 4.57(\mathrm{~s}, 1 \mathrm{H}), 3.19$ $(\mathrm{dd}, J=13.9,3.8 \mathrm{~Hz}, 1 \mathrm{H}), 2.43(\mathrm{~d}, J=14.0 \mathrm{~Hz}, 1 \mathrm{H}) .{ }^{13} \mathrm{C}-\mathrm{NMR}(101 \mathrm{MHz}, \mathrm{DMSO}) \delta$ 167.0, $143.3,138.3,137.2,129.8,129.1,126.2,43.8,39.6$. HRMS $[\mathrm{M}-\mathrm{H}]^{-} \mathrm{m} / z$ calcd. for $\left[\mathrm{C}_{11} \mathrm{H}_{9} \mathrm{O}_{2} \mathrm{~S}\right]^{-}$ 205.0329, found 205.0330.

To synthesize 4-(cyclobut-2-en-1-ylthio)aniline (6d), 3-((4-((tert-butoxycarbonyl)amino) phenyl) thio)cyclobutyl 4-methylbenzenesulfonate ( $22 \mathrm{mg}, 0.049 \mathrm{mmol}, 1.0$ equiv) was dissolved in DCM $(0.7 \mathrm{~mL})$ and trifluoroacetic acid was added $(0.3 \mathrm{~mL})$. The resulting mixture was stirred at room temperature for $1 \mathrm{~h}$. Upon completion monitored by TLC, the reaction mixture was evaporated under reduced pressure. The residue $\mathbf{5} \mathbf{d}^{\prime}$ was used for the next step without further purification. Potassium tert-butoxide $(11 \mathrm{mg}, 0.097 \mathrm{mmol}$, 2.0 equiv) was dissolved in dry DMSO $(0.4 \mathrm{~mL})$ under Ar, forming a colorless solution. Then, a solution of methyl 3-((4-aminophenyl)thio)cyclobutyl 4-methylbenzenesulfonate (17.1 mg, $0.049 \mathrm{mmol}, 1.0$ equiv) in dry DMSO $(0.4 \mathrm{~mL})$ was added slowly to the colorless solution, and the resulting mixture was stirred at room temperature for $1 \mathrm{~h}$. Water was then added slowly, followed by ethyl acetate. The separated water phase was extracted with ethyl acetate three times, and the combined organic phases were washed once with water. The final organic phase was dried over anhydrous $\mathrm{Na}_{2} \mathrm{SO}_{4}$ and evaporated in vacuo. The residue was purified by silica gel column chromatography $(\mathrm{PE} / \mathrm{EA}=5: 1)$ to afford compound $6 \mathrm{~d}(4 \mathrm{mg}, 46 \%)$ as a light yellow solid. ${ }^{1} \mathrm{H}-\mathrm{NMR}\left(400 \mathrm{MHz}, \mathrm{CDCl}_{3}\right) \delta 7.25(\mathrm{~d}$, $J=9.3 \mathrm{~Hz}, 3 \mathrm{H}), 6.61(\mathrm{~d}, J=8.5 \mathrm{~Hz}, 2 \mathrm{H}), 6.05(\mathrm{dd}, J=10.9,2.6 \mathrm{~Hz}, 2 \mathrm{H}), 4.13(\mathrm{~d}, J=3.9 \mathrm{~Hz}$, $1 \mathrm{H}), 3.73(\mathrm{~s}, 2 \mathrm{H}), 2.93(\mathrm{dd}, J=13.8,4.0 \mathrm{~Hz}, 1 \mathrm{H}), 2.44(\mathrm{~d}, J=13.7 \mathrm{~Hz}, 1 \mathrm{H}) .{ }^{13} \mathrm{C}-\mathrm{NMR}(101$ $\left.\mathrm{MHz}, \mathrm{CDCl}_{3}\right) \delta 146.2,138.5,137.0,134.8,122.2,115.4,48.3,39.6$. HRMS $[\mathrm{M}+\mathrm{H}]^{+} \mathrm{m} / z$ calcd. for $\left[\mathrm{C}_{10} \mathrm{H}_{12} \mathrm{NS}\right]^{+}$178.0685, found 178.0687 .

\subsubsection{Synthesis of Compounds $9 a$ and $9 \mathbf{b}$}

A solution of 3-(benzyloxy)cyclobutyl-4-methylbenzenesulfonate (1.0 equiv), compound $8 \mathbf{a}$ or $\mathbf{8 b}$ (2.0 equiv), and $\mathrm{Cs}_{2} \mathrm{CO}_{3}$ (2.0 equiv) was prepared in DMF, and the resulting mixture was stirred at $80{ }^{\circ} \mathrm{C}$ for $8 \mathrm{~h}$. Then the reaction was quenched with water and extracted with ethyl acetate. The combined organic phases were washed with brine, dried over anhydrous $\mathrm{Na}_{2} \mathrm{SO}_{4}$, and evaporated in vacuo. The residue was purified by silica gel column chromatography (PE/EA $=40: 1)$ to afford the desired product $9 \mathbf{a}$ or $\mathbf{9 b}$.

For the synthesis of (3-(benzyloxy)cyclobutoxy)benzene (9a), $1.32 \mathrm{~g}$ of $8 \mathrm{a}$ was used, giving $484 \mathrm{mg}$ of compound $9 \mathrm{a}(48 \%$ yield) as a light yellow oil.

For the synthesis of methyl 3-(4-(3-(benzyloxy)cyclobutoxy)phenyl)-2-((tert-butoxycar bonyl)amino)propanoate (9b), $261 \mathrm{mg}$ of $\mathbf{8 b}$ was used, giving $250 \mathrm{mg}$ of compound $\mathbf{9 b}$ (70\% yield) as a white solid.

\subsubsection{Synthesis of Compounds 10a and 10b}

To prepare 3-phenoxycyclobutyl-4-methylbenzenesulfonate (10a), compound 9a (469 mg, $1.84 \mathrm{mmol}, 1.0$ equiv) was dissolved in ethanol $(10 \mathrm{~mL})$, followed by the addition of $\mathrm{Pd} / \mathrm{C}$ (94 mg). The resulting solution was purged with hydrogen five times, and the mixture was then hydrogenated with a $\mathrm{H}_{2}$ balloon overnight at room temperature. After completion of 
the reaction monitored by TLC, the catalyst was removed by filtration over celite, and the filter cake was washed three times with ethyl acetate. The combined organic layers were evaporated in vacuo, affording a crude mixture that was used in the next step without purification. TEA (772 $\mu \mathrm{L}, 5.53 \mathrm{mmol}, 3.0$ equiv) and DMAP ( $45 \mathrm{mg}, 0.37 \mathrm{mmol}, 0.2 \mathrm{equiv}$ ) were dissolved in DCM $(4 \mathrm{~mL})$ under Ar and added to the crude mixture. The resulting mixture was cooled to $0^{\circ} \mathrm{C}$, and a solution of $\mathrm{TsCl}(1.05 \mathrm{~g}, 5.53 \mathrm{mmol}, 3.0$ equiv) in DCM (6 $\mathrm{mL}$ ) was added. The reaction mixture was stirred at room temperature for $20 \mathrm{~h}$. Then the reaction was quenched with water and extracted with ethyl acetate. The combined organic phases were washed with brine, dried over anhydrous $\mathrm{Na}_{2} \mathrm{SO}_{4}$, and evaporated in vacuo. The residue was purified by silica gel column chromatography ( $\mathrm{PE} / \mathrm{EA}=5: 1$ ) to afford 10a in $86 \%$ yield $(508 \mathrm{mg})$ as a light yellow oil. ${ }^{1} \mathrm{H}-\mathrm{NMR}\left(400 \mathrm{MHz}, \mathrm{CDCl}_{3}\right) \delta 7.79(d, J=8.2 \mathrm{~Hz}$, $2 \mathrm{H}), 7.35(d, J=8.3 \mathrm{~Hz}, 2 \mathrm{H}), 7.25(t, J=8.0 \mathrm{~Hz}, 2 \mathrm{H}), 6.94(t, J=7.4 \mathrm{~Hz}, 1 \mathrm{H}), 6.71(d, J=7.9 \mathrm{~Hz}$, 2H), 5.11-5.00 (m, 1H), 4.84-4.79 (m, 1H), 2.67-2.58 (m, 2H), 2.54-2.48 (m, 2H), $2.45(\mathrm{~s}, 3 \mathrm{H})$. ${ }^{13} \mathrm{C}-\mathrm{NMR}\left(101 \mathrm{MHz}, \mathrm{CDCl}_{3}\right) \delta 157.2,145.1,133.7,130.1,129.7,128.0,121.3,114.9,73.2,68.2$, 37.8, 21.8. HRMS $[\mathrm{M}+\mathrm{Na}]^{+} \mathrm{m} / z$ calcd. for $\left[\mathrm{C}_{17} \mathrm{H}_{18} \mathrm{NaO}_{4} \mathrm{~S}\right]^{+} 341.0818$, found 341.0826.

Methyl 2-((tert-butoxycarbonyl)amino)-3-(4-(3-(tosyloxy)cyclobutoxy)phenyl)propanoate (10b) was isolated in 70\% yield from compound $9 \mathrm{~b}$ and $\mathrm{TsCl}$ as a light red solid by a method analogous to that described for the synthesis of $10 \mathrm{a}$ above.

\subsubsection{Synthesis of Compounds $\mathbf{1 1 a}$ and $\mathbf{1 1 b}$}

To prepare cyclobut-2-en-1-yloxy)benzene (11a), potassium tert-butoxide (198 mg, $1.77 \mathrm{mmol}, 2.0$ equiv) was dissolved in dry DMSO (2 mL) under Ar, forming a colorless solution. A solution of compound 10a (281 mg, $0.88 \mathrm{mmol}, 1.0$ equiv) in dry DMSO (2 mL) was then added slowly to the colorless solution, and the reaction mixture was left stirring at room temperature for $1 \mathrm{~h}$. After completion of the reaction monitored by TLC, water was added slowly, followed by ethyl acetate. The separated water phase was extracted with ethyl acetate three times, and the combined organic layers were washed once with water. The final organic phase was dried over anhydrous $\mathrm{Na}_{2} \mathrm{SO}_{4}$ and evaporated in vacuo. The residue was purified by silica gel column chromatography (PE) to afford 11a $(73.6 \mathrm{mg}, 57 \%)$ as a colorless oil. ${ }^{1} \mathrm{H}-\mathrm{NMR}\left(400 \mathrm{MHz}, \mathrm{CDCl}_{3}\right) \delta 7.28(t, J=9.8 \mathrm{~Hz}, 2 \mathrm{H}), 6.95(t, J=7.4 \mathrm{~Hz}$, $1 \mathrm{H}), 6.89(d, J=7.8 \mathrm{~Hz}, 2 \mathrm{H}), 6.31(d, J=33.7 \mathrm{~Hz}, 2 \mathrm{H}), 5.10(d, J=3.2 \mathrm{~Hz}, 1 \mathrm{H}), 3.00(d d, J=13.4$, $3.5 \mathrm{~Hz}, 1 \mathrm{H}), 2.63(d d, J=13.4,1.0 \mathrm{~Hz}, 1 \mathrm{H}) .{ }^{13} \mathrm{C}-\mathrm{NMR}\left(101 \mathrm{MHz}, \mathrm{CDCl}_{3}\right) \delta 158.2,139.3,137.0$, $129.7,121.0,115.0,74.5,39.7$.

The compound 2-((tert-butoxycarbonyl)amino)-3-(4-(cyclobut-2-en-1-yloxy)phenyl) propanoic acid (11b) was obtained in $45 \%$ yield as a white solid from compound $\mathbf{1 0 b}$ and potassium tert-butoxide by a method analogous to that described for the synthesis of 11a above. ${ }^{1} \mathrm{H}-\mathrm{NMR}\left(400 \mathrm{MHz}, \mathrm{DMSO}-d_{6}\right) \delta 12.49(s, 1 \mathrm{H}), 7.11(d, J=8.4 \mathrm{~Hz}, 2 \mathrm{H}), 6.98(d$, $J=8.3 \mathrm{~Hz}, 1 \mathrm{H}), 6.77(d, J=8.5 \mathrm{~Hz}, 2 \mathrm{H}), 6.30(d, J=32.6 \mathrm{~Hz}, 2 \mathrm{H}), 5.02(d, J=2.8 \mathrm{~Hz}, 1 \mathrm{H})$, $4.02-3.96(m, 1 \mathrm{H}), 2.98-2.84(m, 2 \mathrm{H}), 2.71(d d, J=13.6,10.3 \mathrm{~Hz}, 1 \mathrm{H}), 2.48-2.35(m, 2 \mathrm{H}), 1.28$ $(s, 8 \mathrm{H}) .{ }^{13} \mathrm{C}-\mathrm{NMR}\left(101 \mathrm{MHz}, \mathrm{DMSO}-d_{6}\right) \delta 173.7,156.2,155.5,138.9,137.2,130.2,130.1,114.4$, 78.0, 73.8, 55.4, 40.4, 35.7, 28.2, 27.9. HRMS [M-H] ${ }^{-} m / z$ calcd. for $\left[\mathrm{C}_{18} \mathrm{H}_{22} \mathrm{NO}_{5}\right]^{-} 332.1503$, found 332.1493 .

\subsubsection{Synthesis of 5-((4-(Cyclobut-2-en-1-Ylthio)Phenyl)Amino)-5-Oxopentanoic Acid (16)}

A mixture of compound $6 \mathrm{~d}(5 \mathrm{mg}, 0.028 \mathrm{mmol}, 1.0$ equiv), glutaric anhydride $(3.5 \mathrm{mg}$, $0.031 \mathrm{mmol}, 1.1$ equiv), and TEA (10 $\mu \mathrm{L}, 0.07 \mathrm{mmol}, 2.5$ equiv) was dissolved in DCM $(0.5 \mathrm{~mL})$ under Ar. The resulting mixture was stirred at room temperature for $3 \mathrm{~h}$, and then quenched with water and extracted with ethyl acetate. The combined organic phases were washed with brine, dried over anhydrous $\mathrm{Na}_{2} \mathrm{SO}_{4}$, and evaporated in vacuo. Due to the small scale of the reaction, the residue was purified by thin-layer chromatography to afford $6.2 \mathrm{mg}(75 \%)$ of 16 as a white solid. ${ }^{1} \mathrm{H}-\mathrm{NMR}\left(400 \mathrm{MHz}, \mathrm{DMSO}-d_{6}\right) \delta 9.96(s, 1 \mathrm{H}), 7.56(d$, $J=8.6 \mathrm{~Hz}, 2 \mathrm{H}), 7.28(d, J=8.6 \mathrm{~Hz}, 2 \mathrm{H}), 6.15(d d, J=15.0,2.6 \mathrm{~Hz}, 2 \mathrm{H}), 4.30(d, J=3.6 \mathrm{~Hz}, 1 \mathrm{H})$, $3.00(d d, J=13.8,3.9 \mathrm{~Hz}, 1 \mathrm{H}), 2.35(d d, J=13.7,6.2 \mathrm{~Hz}, 3 \mathrm{H}), 2.26(t, J=7.3 \mathrm{~Hz}, 2 \mathrm{H}), 1.80(p$, $J=7.3 \mathrm{~Hz}, 2 \mathrm{H}) .{ }^{13} \mathrm{C}-\mathrm{NMR}\left(101 \mathrm{MHz}, \mathrm{DMSO}-d_{6}\right): \delta 174.2,170.8,138.1,137.4,131.0,128.3$, 
119.5, 46.1, 39.4, 35.4, 33.1, 20.5. HRMS $[\mathrm{M}+\mathrm{Na}]^{+} \mathrm{m} / z$ calcd. for $\left[\mathrm{C}_{15} \mathrm{H}_{17} \mathrm{NNaO}_{3} \mathrm{~S}\right]^{+} 314.0821$, found 314.0821 .

3.2.9. Synthesis of 2,5-Dioxopyrrolidin-1-yl-5-((4-(Cyclobut-2-en-1-Ylthio)Phenyl)Amino)5-Oxopentanoate (17)

A mixture of compound 16 (6.2 mg, $0.021 \mathrm{mmol}, 1.0$ equiv), $\mathrm{N}, \mathrm{N}$-disuccinimidyl carbonate (DSC) $(5.4 \mathrm{mg}, 0.021 \mathrm{mmol}, 1.0$ equiv), and TEA ( $4.5 \mu \mathrm{L}, 0.032 \mathrm{mmol}, 1.5$ equiv) was dissolved in tetrahydrofuran (THF) $(0.5 \mathrm{~mL})$ under Ar. The resulting mixture was stirred at room temperature for $4 \mathrm{~h}$. After reaction completion, the reaction was quenched with water and extracted with ethyl acetate. The combined organic phases were washed with brine, dried over anhydrous $\mathrm{Na}_{2} \mathrm{SO}_{4}$, and evaporated in vacuo. Similarly to analogue 16, the residue was purified by thin-layer chromatography to afford the desired product 17 as a white solid in $51 \%$ yield $(4.2 \mathrm{mg}) .{ }^{1} \mathrm{H}-\mathrm{NMR}\left(400 \mathrm{MHz}, \mathrm{CDCl}_{3}\right) \delta 8.02(\mathrm{~s}, 1 \mathrm{H}), 7.47\left(d_{\text {, }}\right.$ $J=8.5 \mathrm{~Hz}, 2 \mathrm{H}), 7.30(d, J=8.6 \mathrm{~Hz}, 2 \mathrm{H}), 6.09(d d, J=21.8,2.5 \mathrm{~Hz}, 2 \mathrm{H}), 4.26(d, J=3.5 \mathrm{~Hz}$, $1 \mathrm{H}), 3.02(d d, J=13.8,3.6 \mathrm{~Hz}, 1 \mathrm{H}), 2.88(s, 4 \mathrm{H}), 2.75-2.68(m, 2 \mathrm{H}), 2.47(d d, J=12.9,5.8 \mathrm{~Hz}$, 3H), 2.23-2.12 (m, 2H). ${ }^{13} \mathrm{C}-\mathrm{NMR}\left(101 \mathrm{MHz}, \mathrm{CDCl}_{3}\right) \delta 170.2,169.7,168.5,138.0,137.6$, $136.9,131.7,130.9,120.3,47.0,40.0,35.5,30.0,25.8,21.2$. HRMS $[\mathrm{M}+\mathrm{Na}]^{+} \mathrm{m} / z$ calcd. for $\left[\mathrm{C}_{19} \mathrm{H}_{20} \mathrm{~N}_{2} \mathrm{NaO}_{5} \mathrm{~S}\right]^{+}$411.0985, found 411.0989.

\subsection{Stability of the Cyclobutene Derivatives $\mathbf{6 a - 6 d , 1 1 a}$, and $\mathbf{1 1 b}$}

To examine the stability of the synthesized analogues for potential applications in bioorthogonal chemistry, dienophiles $\mathbf{6 a - 6 d , 1 1 a}$, and $\mathbf{1 1} \mathbf{b}$ were dissolved in a DMF/PBS mixture (1:1) at a final concentration of $0.5 \mathrm{mM}$ at pH 7.4 and $37^{\circ} \mathrm{C}$. Samples were monitored at 0,12 , and $24 \mathrm{~h}$ using high-performance liquid chromatography ( $3 \mu \mathrm{L}$ injected per time point). Absorbance was measured at $260 \mathrm{~nm}$ for $\mathbf{6 b}, 280 \mathrm{~nm}$ for 11a and 11b, $254 \mathrm{~nm}$ for $\mathbf{6 a}$ and $\mathbf{6 d}$, and $300 \mathrm{~nm}$ for $\mathbf{6 c}$. The peak area at each time point was expressed as a percentage of the area at $0 \mathrm{~h}$.

\subsection{Kinetics of the Reactions between Cyclobutene Derivatives and Tetrazine}

Tetrazine 12 was dissolved in a DMF $/ \mathrm{H}_{2} \mathrm{O}(1: 1)$ mixture at a final concentration of $0.5 \mathrm{mM}$ at $37{ }^{\circ} \mathrm{C}$. Dienophiles $\mathbf{6 a - 6 d}, \mathbf{1 1 a}$, and $\mathbf{1 1 b}$ were then added to the quartz cuvettes with final concentration of $5 \mathrm{mM}$. A Quawell Q6000+ UV-Vis spectrophotometer was used to monitor the disappearance of the characteristic absorption peak of tetrazine at $520 \mathrm{~nm}$ at 10-min intervals for a duration of $6 \mathrm{~h}$. The experimental data were processed using GraphPad Prism 6.0.

\subsection{IEDDA-Oxidation Cascade Reaction of Cyclobutene $\mathbf{6} \boldsymbol{a}$ with Dipyridinetetrazine $\mathbf{1 2}$}

Compound $6 \mathbf{6}$ (5 mg, $0.028 \mathrm{mmol}, 1.05$ equiv) and dipyridine tetrazine $12(6.38 \mathrm{mg}$, $0.027 \mathrm{mmol}, 1.0$ equiv) were dissolved in THF $(0.3 \mathrm{~mL})$ and $\mathrm{H}_{2} \mathrm{O}(0.1 \mathrm{~mL})$. The resulting mixture was stirred at $60^{\circ} \mathrm{C}$ for $2 \mathrm{~h}$. Upon completion monitored by HPLC, to the reaction mixture was added DDQ $(6.74 \mathrm{mg}, 0.029 \mathrm{mmol}, 1.1$ equiv). The resulting mixture was stirred at room temperature for $1.5 \mathrm{~h}$. Upon completion monitored by HPLC, the reaction was quenched with water and extracted with ethyl acetate. The combined organic phase was washed with brine, dried over anhydrous $\mathrm{Na}_{2} \mathrm{SO}_{4}$, and evaporated under reduced pressure. The residue was purified via silica column chromatography to afford the product $14(8.5 \mathrm{mg}, 82 \%$ yield $)$ as a light red solid.

\subsection{Protein Labeling}

\subsubsection{Protein Modification In Vitro}

The cyclobutene derivative $17(0.5 \mu \mathrm{L}, 50 \mathrm{mM}, 10.0$ equiv) was mixed with BSA ( $5 \mu \mathrm{L}$, $0.5 \mathrm{mM}$ in PBS) in sodium bicarbonate buffer ( $39 \mu \mathrm{L}, \mathrm{pH}$ 8.2) containing DMSO (4.5 $\mu \mathrm{L})$. The mixture was kept at room temperature for $2 \mathrm{~h}$, then excess $\mathbf{1 7}$ was removed using a Zeba desalting spin column $(0.5 \mathrm{~mL})$. The modified protein was recovered in PBS and its concentration quantified at $19.2 \mu \mathrm{M}$ based on Quawell Q6000+ UV-Vis absorption scanning. 


\subsubsection{Protein Labeling In Vitro}

Three samples were incubated at $37^{\circ} \mathrm{C}$ for $4 \mathrm{~h}$ : the BSA-labeling reaction containing H-Tz-Cy5 (2.5 $\mu \mathrm{L}, 5 \mathrm{mM}$ in DMSO) and cyclobutene-modified BSA $(22.5 \mu \mathrm{L}, 19.2 \mu \mathrm{M}$ in PBS), giving a final dye concentration of $250 \mu \mathrm{M}$ or $500 \mu \mathrm{M}$; a negative-control reaction containing H-Tz-Cy5 $(2.5 \mu \mathrm{L}, 5 \mathrm{mM}$ in DMSO) and unmodified BSA $(22.5 \mu \mathrm{L}, 19.2 \mu \mathrm{M}$ in PBS), again giving a final dye concentration of $250 \mu \mathrm{M}$ or $500 \mu \mathrm{M}$; and a "blank" reaction of only neat, unmodified BSA ( $25 \mu \mathrm{L}, 19.2 \mu \mathrm{M}$ in PBS). After incubation, all of the samples were passed through a Zeba desalting spin column $(0.5 \mathrm{~mL})$ to remove excess dye. All of the column eluates contained the same concentration of about $0.4 \mathrm{mg} / \mathrm{mL}$, based on Quawell Q6000+ spectrophotometry. An aliquot $(20 \mu \mathrm{L})$ of each sample was mixed with $2 \mu \mathrm{L}$ of 5X SDS-PAGE loading buffer and vortexed for $10 \mathrm{sec}$, and an aliquot $(15 \mu \mathrm{L})$ of supernatant was loaded onto SDS-PAGE gels. The gels were imaged for fluorescence using the ChemiDoc ${ }^{\mathrm{TM}}$ MP imaging system (Bio-Rad), then stained with Coomassie blue and imaged under visible light.

3.6.3. Rough Estimation Method of the Yield of the Labeling Reaction on the Model BSA Protein

The second-order reaction rate constant of compound $\mathbf{6 d}$ and 3-phenyl-1,2,4,5-tetrazine $(\mathrm{H}-\mathrm{Tz}-\mathrm{Ph})$ was determined by a method similar to that described above for determining reaction kinetics, giving $k_{2}=0.056 \mathrm{M}^{-1} \mathrm{~s}^{-1}$.

The first-order reaction rate constant $\left(k_{1}\right)$ was determined according to the formula:

$$
k_{1}=c k_{2}
$$

$c$ is the concentration of the reactant, which is greatly excessive.

The half-life $\left(t_{1 / 2}\right)$ of the reaction was calculated with the following formula:

$$
t_{1 / 2}=\frac{\ln 2}{k_{1}}
$$

The final dye concentration in the labeling reaction was $500 \mu \mathrm{M}$ and the reaction time was $4 \mathrm{~h}$. The half-life $\left(t_{1 / 2}\right)$ was calculated according to the above formulas and it was about $6.875 \mathrm{~h}$. A rough estimation of the yield of the labeling reaction was about $29.1 \%$, which is determined according to the formula:

$$
\text { Yield }(4 \mathrm{~h})=\frac{4 \mathrm{~h}}{t_{1 / 2}} \times 50 \%
$$

\section{Conclusions}

We developed concise synthesis of a series of novel aryl-substituted cyclobutene derivatives. These small, strained cyclobutenes are stable enough to serve as small dienophiles for bioorthogonal tetrazine ligations that proceed with good kinetics and high yields. Yet, the aryl-substituted cyclobutenes might not be small enough for use as mini-tags for bioorthogonal metabolic labeling applications and of relatively poor water solubility. Our synthesis strategy provides a potential way to synthesize hydrophilic alkysubstituted cyclobutene. Based on these promising results, we expect that the synthesis of additional aryl-substituted cyclobutene analogues will significantly enrich available bioorthogonal tools and facilitate the development of new biomedical applications.

Author Contributions: H.W. and H.S. designed the experiments; J.S., J.L. and H.S. performed the experiments and analyzed the data; J.S. and C.L. wrote the original draft preparation; H.W., J.L. and H.S. reviewed and edited the manuscript. All authors have read and agreed to the published version of the manuscript. 
Funding: This work was supported by the Key Research and Development Projects in Sichuan Province (2020YFS0123); National Natural Science Foundation (21801178); and 1.3.5 project for disciplines of excellence, West China Hospital, Sichuan University.

Institutional Review Board Statement: Not applicable.

Informed Consent Statement: Not applicable.

Data Availability Statement: Data sharing not applicable.

Acknowledgments: We acknowledge the Analytical \& Testing Center of Sichuan University for NMR Tests.

Conflicts of Interest: The authors declare no conflict of interest.

Sample Availability: Not available.

\section{References}

1. Lang, K.; Chin, J.W. Bioorthogonal Reactions for Labeling Proteins. ACS Chem. Biol. 2014, 9, 16-20.

2. Patterson, D.M.; Nazarova, L.A.; Prescher, J.A. Finding the Right (Bioorthogonal) Chemistry. ACS Chem. Biol. 2014, 9, 592-605. [CrossRef] [PubMed]

3. Devaraj, N.K. The Future of Bioorthogonal Chemistry. ACS Cent. Sci. 2018, 4, 952-959. [CrossRef] [PubMed]

4. Nguyen, S.S.; Prescher, J.A. Developing bioorthogonal probes to span a spectrum of reactivities. Nat. Rev. Chem. 2020, 4, 476-489.

5. Oliveira, B.L.; Guo, Z.; Bernardes, G.J.L. Inverse electron demand Diels-Alder reactions in chemical biology. Chem. Soc. Rev. 2017, 46, 4895-4950. [CrossRef]

6. Wu, H.; Devaraj, N.K. Advances in Tetrazine Bioorthogonal Chemistry Driven by the Synthesis of Novel Tetrazines and Dienophiles. Acc. Chem. Res. 2018, 51, 1249-1259.

7. Kui, W.; Nathan, Y.; Sangeetha, S.; Amir, M.; Michael, Z.; Jose, M.M.O.; Maksim, R. Click Activated Protodrugs Against Cancer Increase the Therapeutic Potential of Chemotherapy through Local Capture and Activation. ChemRxiv 2020. [CrossRef]

8. Wilkovitsch, M.; Haider, M.; Sohr, B.; Herrmann, B.; Klubnick, J.; Weissleder, R.; Carlson, J.C.T.; Mikula, H. A Cleavable $\mathrm{C}_{2}$-Symmetric trans-Cyclooctene Enables Fast and Complete Bioorthogonal Disassembly of Molecular Probes. J. Am. Chem. Soc. 2020, 142, 19132-19141.

9. Blackman, M.L.; Royzen, M.; Fox, J.M. Tetrazine Ligation: Fast Bioconjugation Based on Inverse-Electron-Demand Diels-Alder Reactivity. J. Am. Chem. Soc. 2008, 130, 13518-13519.

10. Taylor, M.T.; Blackman, M.L.; Dmitrenko, O.; Fox, J.M. Design and Synthesis of Highly Reactive Dienophiles for the Tetrazinetrans-Cyclooctene Ligation. J. Am. Chem. Soc. 2011, 133, 9646-9649.

11. Darko, A.; Wallace, S.; Dmitrenko, O.; Machovina, M.M.; Mehl, R.A.; Chin, J.W.; Fox, J.M. Conformationally strained transcyclooctene with improved stability and excellent reactivity in tetrazine ligation. Chem. Sci. 2014, 5, 3770-3776. [PubMed]

12. Mejia Oneto, J.M.; Khan, I.; Seebald, L.; Royzen, M. In Vivo Bioorthogonal Chemistry Enables Local Hydrogel and Systemic Pro-Drug to Treat Soft Tissue Sarcoma. ACS Cent. Sci. 2016, 2, 476-482. [CrossRef] [PubMed]

13. Rossin, R.; van Duijnhoven, S.M.; Ten Hoeve, W.; Janssen, H.M.; Kleijn, L.H.; Hoeben, F.J.; Versteegen, R.M.; Robillard, M.S. Triggered Drug Release from an Antibody-Drug Conjugate Using Fast "Click-to-Release" Chemistry in Mice. Bioconjug. Chem. 2016, 27, 1697-1706. [CrossRef] [PubMed]

14. Carlson, J.C.T.; Mikula, H.; Weissleder, R. Unraveling Tetrazine-Triggered Bioorthogonal Elimination Enables Chemical Tools for Ultrafast Release and Universal Cleavage. J. Am. Chem. Soc. 2018, 140, 3603-3612. [PubMed]

15. Versteegen, R.M.; Ten Hoeve, W.; Rossin, R.; de Geus, M.A.R.; Janssen, H.M.; Robillard, M.S. Click-to-Release from transCyclooctenes: Mechanistic Insights and Expansion of Scope from Established Carbamate to Remarkable Ether Cleavage. Angew. Chem. Int. Ed. 2018, 57, 10494-10499.

16. Chen, W.; Wang, D.; Dai, C.; Hamelberg, D.; Wang, B. Clicking 1,2,4,5-tetrazine and cyclooctynes with tunable reaction rates. Chem. Commun. 2012, 48, 1736-1738. [CrossRef]

17. Agarwal, P.; Beahm, B.J.; Shieh, P.; Bertozzi, C.R. Systemic Fluorescence Imaging of Zebrafish Glycans with Bioorthogonal Chemistry. Angew. Chem. Int. Ed. 2015, 54, 11504-11510.

18. Mao, W.; Tang, J.; Dai, L.; He, X.; Li, J.; Cai, L.; Liao, P.; Jiang, R.; Zhou, J.; Wu, H. A General Strategy to Design Highly Fluorogenic Far-Red and Near-Infrared Tetrazine Bioorthogonal Probes. Angew. Chem. Int. Ed. 2020. [CrossRef]

19. Patterson, D.M.; Nazarova, L.A.; Xie, B.; Kamber, D.N.; Prescher, J.A. Functionalized cyclopropenes as bioorthogonal chemical reporters. J. Am. Chem. Soc. 2012, 134, 18638-18643.

20. Yang, J.; Šečkutè, J.; Cole, C.M.; Devaraj, N.K. Live-cell imaging of cyclopropene tags with fluorogenic tetrazine cycloadditions. Angew. Chem. Int. Ed. 2012, 51, 7476-7479. [CrossRef]

21. Yang, J.; Liang, Y.; Šečkutè, J.; Houk, K.N.; Devaraj, N.K. Synthesis and reactivity comparisons of 1-methyl-3-substituted cyclopropene mini-tags for tetrazine bioorthogonal reactions. Chem. Eur. J. 2014, 20, 3365-3375. [CrossRef] [PubMed]

22. Ravasco, J.M.J.M.; Monteiro, C.M.; Trindade, A.F. Cyclopropenes: A new tool for the study of biological systems. Org. Chem. Front. 2017, 4, 1167-1198. [CrossRef] 
23. Devaraj, N.K.; Weissleder, R.; Hilderbrand, S.A. Tetrazine-Based Cycloadditions: Application to Pretargeted Live Cell Imaging. Bioconjug. Chem. 2008, 19, 2297-2299. [CrossRef] [PubMed]

24. Vrabel, M.; Kolle, P.; Brunner, K.M.; Gattner, M.J.; Lopez-Carrillo, V.; de Vivie-Riedle, R.; Carell, T. Norbornenes in inverse electron-demand Diels-Alder reactions. Chem. Eur. J. 2013, 19, 13309-13312. [CrossRef] [PubMed]

25. Wu, H.; Cisneros, B.T.; Cole, C.M.; Devaraj, N.K. Bioorthogonal tetrazine-mediated transfer reactions facilitate reaction turnover in nucleic acid-templated detection of microRNA. J. Am. Chem. Soc. 2014, 136, 17942-17945.

26. Xu, M.; Tu, J.; Franzini, R.M. Rapid and efficient tetrazine-induced drug release from highly stable benzonorbornadiene derivatives. Chem. Commun. 2017, 53, 6271-6274. [CrossRef]

27. Xu, M.; Galindo-Murillo, R.; Cheatham, T.E.; Franzini, R.M. Dissociative reactions of benzonorbornadienes with tetrazines: Scope of leaving groups and mechanistic insights. Org. Biomol. Chem. 2017, 15, 9855-9865. [CrossRef]

28. Wu, H.; Alexander, S.C.; Jin, S.; Devaraj, N.K. A Bioorthogonal Near-Infrared Fluorogenic Probe for mRNA Detection. J. Am. Chem. Soc. 2016, 138, 11429-11432. [CrossRef]

29. Jiménez-Moreno, E.; Guo, Z.; Oliveira, B.L.; Albuquerque, I.S.; Kitowski, A.; Guerreiro, A.; Boutureira, O.; Rodrigues, T.; Jiménez-Osés, G.; Bernardes, G.J. Vinyl Ether/Tetrazine Pair for the Traceless Release of Alcohols in Cells. Angew. Chem. Int. Ed. 2017, 56, 243-247. [CrossRef]

30. Xie, X.; Li, B.; Wang, J.; Zhan, C.; Huang, Y.; Zeng, F.; Wu, S. Tetrazine-Mediated Bioorthogonal System for Prodrug Activation, Photothermal Therapy, and Optoacoustic Imaging. ACS Appl. Mater. Interfaces 2019, 11, 41875-41888.

31. Xie, X.; Li, B.; Wang, J.; Zhan, C.; Huang, Y.; Zeng, F.; Wu, S. Bioorthogonal Nanosystem for Near-Infrared Fluorescence Imaging and Prodrug Activation in Mouse Model. ACS Mater. Lett. 2019, 1, 549-557.

32. Wang, Y.; Zhang, C.; Wu, H.; Feng, P. Activation and Delivery of Tetrazine-Responsive Bioorthogonal Prodrugs. Molecules 2020, 25, 5640. [CrossRef]

33. Liu, K.; Enns, B.; Evans, B.; Wang, N.; Shang, X.; Sittiwong, W.; Dussault, P.H.; Guo, J. A genetically encoded cyclobutene probe for labelling of live cells. Chem. Commun. 2017, 53, 10604-10607. [CrossRef] [PubMed]

34. Kamber, D.N.; Nazarova, L.A.; Liang, Y.; Lopez, S.A.; Patterson, D.M.; Shih, H.W.; Houk, K.N.; Prescher, J.A. Isomeric cyclopropenes exhibit unique bioorthogonal reactivities. J. Am. Chem. Soc. 2013, 135, 13680-13683. [CrossRef] [PubMed]

35. Engelsma, S.B.; Willems, L.I.; van Paaschen, C.E.; van Kasteren, S.I.; van der Marel, G.A.; Overkleeft, H.S.; Filippov, D.V. Acylazetine as a dienophile in bioorthogonal inverse electron-demand Diels-Alder ligation. Org. Lett. 2014, 16, $2744-2747$. [CrossRef] [PubMed]

36. Engelsma, S.B.; van den Ende, T.C.; Overkleeft, H.S.; van der Marel, G.A.; Filippov, D.V. Reaction Rates of Various N-Acylenamines in the Inverse-Electron-Demand Diels-Alder Reaction. Eur. J. Org. Chem. 2018, 2018, 2587-2591.

37. Rieder, U.; Luedtke, N.W. Alkene-Tetrazine Ligation for Imaging Cellular DNA. Angew. Chem. Int. Ed. 2014, 53, 9168-9172. [CrossRef] 